dr inz. Pawet Kuligowski

mgr inz. Marcin Kruś

Instytut Pojazdów Szynowych ,TABOR”

\title{
Lekkie struktury konstrukcyjne w budowie ustroju nośnego pojazdu szynowego
}

\begin{abstract}
Zwiększone wymagania przewozów kolejowych, zarówno $w$ zakresie ilości jak $i$ prędkości, zmuszaja do stosowania pojazdów szynowych o coraz liejszych rozwiqzaniach konstrukcyjnych. Zastosowanie lekkich, a jednocześnie wysokowytrzymatych struktur wielowarstwowych z cata pewnościa ułatwi realizacje powyższego zadania. W pracy przedstawiono, na przykładzie wagonu osobowego, koncepcje budowy ustroju nośnego pojazdu szynowego polegajace na zastapieniu klasycznej konstrukcji szkieletowej, rozwiazaniami wykorzystujacymi aluminiowe trójwarstwowe elementy powierzchniowe $z$ rdzeniem wykonanym z pofałdowanej blachy. Ocena możliwości zastosowania takich konstrukcji musi być poprzedzona niezbędnymi analizami sztywności $i$ wytrzymałości, które przeprowadzono metoda elementów skończonych. Wyniki obliczeń dla rozważanych koncepcji porównano z rezultatami dla wersji szkieletowej i na tej podstawie przedstawiono wstepnq ocene ich przydatności do zastosowania. Praca powstała $w$ ramach realizacji projektu rozwojowego Nr 100047 06: „Konstrukcja pojazdu szynowego z zastosowaniem najnowszych lekkich materiałów o wysokich parametrach wytrzymałościowych i o minimalnym oddziatywaniu na środowisko naturalne".
\end{abstract}

\section{Wprowadzenie}

Obniżenie masy własnej środków transportu jest jednym $\mathrm{z}$ podstawowych wymagań stawianych nowocześnie zorganizowanym przewozom, $w$ tym także kolejowym. Jedną z możliwości jest wykorzystanie w konstrukcjach nośnych pojazdów lekkich np. aluminiowych, a jednocześnie wysokowytrzymałych elementów powierzchniowych o budowie wielowarstwowej. Najczęściej zbudowane są z gładkich blach, zwanych okładzinami, przedzielonych rdzeniem o różnorodnej strukturze wykonanej np. ze spienionego tworzywa (sztucznego jak również z piany metalowej), ,plastra miodu” lub pofałdowanej blachy. Podstawy teorii struktur wielowarstwowych opisano $\mathrm{w}$ [1] i [2].

Konstrukcje trójwarstwowe $\mathrm{w}$ porównaniu do konwencjonalnych jednorodnych blach posiadaja następujące zalety: 
- większa sztywność i jednocześnie mniejsza masa,

- możliwość eliminacji dodatkowych wzmocnień i usztywnień,

- mniej pracochłonne wytwarzanie,

- dobra izolacja termiczna,

- dobre thumienie drgań oraz hałasu.

$\mathrm{W}$ ramach prac związanych $\mathrm{z}$ realizacją zadań projektu rozwojowego podjęto próby sprawdzenia przydatności do zastosowania, w budowie konstrukcji nośnej pojazdu szynowego, aluminiowych elementów powierzchniowych o strukturze trójwarstwowej, głównie na przykładzie wagonu osobowego.

W pierwszej kolejności konieczne było opracowanie modeli obliczeniowych MES (Metoda Elementów Skończonych) struktur trójwarstwowych z różnym wypełnieniem. Przeprowadzono szereg analiz w celu wyznaczenia podstawowych własności mechanicznych. Weryfikacje przygotowanych modeli przeprowadzono porównując wyniki obliczeń z rezultatami badań doświadczalnych rzeczywistych próbek wykonanych na stanowisku badawczym. Rezultaty tych działań omówiono w [3]. Na podstawie uzyskanych wyników wytypowano do dalszych zastosowań elementy powierzchniowe trójwarstwowe $\mathrm{z}$ rdzeniem z blachy falistej. Widok ogólny fragmentu takiego elementu oraz przykładowy przekrój poprzeczny przedstawiono na rys. 1.1. Poszczególne elementy wykonane są z blach aluminiowych, a połączenie okładzin $\mathrm{z}$ rdzeniem zrealizowane jest za pomocą klejenia.
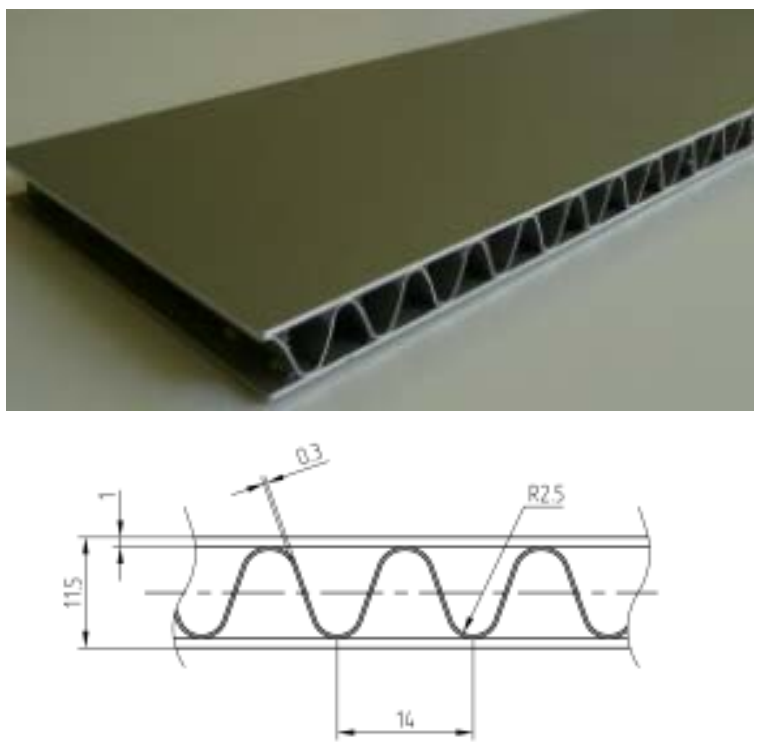

Rys. 1.1. Widok ogólny trójwarstwowego elementu powierzchniowego $\mathrm{z}$ rdzeniem $\mathrm{z}$ blachy falistej i jego przekroju poprzecznego

W dalszej kolejności rozważono koncepcje polegające na stopniowym wprowadzaniu elementów trójwarstwowych do dotychczasowych konstrukcji nośnych szkieletowych. W pierwszym etapie analizowane elementy zastosowano $\mathrm{w}$ ścianie bocznej zastępując płaską blachę poszyciową oraz pozostawiając tylko słupki pionowe. W kolejnym kroku dodatkowo zastąpiono całą konstrukcję dachu walcową powłoką trójwarstwową, a wprowadzenie panelu trójwarstwowego zamiast blachy podłogi stanowi ostatni etap rozważań zmian konstrukcji nośnej. Ocena możliwości zastosowania takich konstrukcji musi być poprzedzona niezbędnymi analizami sztywności i wytrzymałości, które przeprowadzono metodą elementów skończonych.

W niniejszym artykule omówiono opracowane modele obliczeniowe MES. Wyniki obliczeń dla rozważanych koncepcji porównano z rezultatami dla klasycznej wersji szkieletowej i na tej podstawie przedstawiono wstępną ocenę ich przydatności do zastosowania.

\section{Modelowanie konstrukcji nośnej nadwozia}

\subsection{Koncepcje rozwiązań konstrukcyjnych}

Propozycje koncepcji rozwiązań konstrukcyjnych ustroju nośnego pojazdu szynowego z zastosowaniem lekkich metalowych struktur o podwyższonej nośności opracowano bazując na konstrukcji nadwozia pasażerskiego pojazdu szynowego. Przykładami takiego pojazdu mogą być tradycyjne wagony osobowe przeznaczone do ruchu dalekobieżnego lub człony toczne zespołów trakcyjnych.

Wspomniane konstrukcje, projektowane od wielu lat, mają zazwyczaj klasyczną budowę szkieletową. Podstawę stanowi szkielet, pospawany najczęściej z kształtowników, który pokryty jest poszyciem wykonanym $\mathrm{z}$ blachy.

Koncepcje nowych rozwiązań konstrukcyjnych bazują na stopniowym ograniczaniu szkieletu nadwozia z jednoczesnym zastapieniem blachy poszyciowej metalowymi strukturami trójwarstwowymi.

Rozpatrzono kilka koncepcji rozwiązań konstrukcyjnych różniących się obszarami, w których blachę poszyciową zastąpiono strukturami trójwarstwowymi, a mianowicie:

I - w ścianach bocznych szkielet ograniczono tylko do słupków pionowych, a płaską blachę poszyciową zastapiono strukturą trójwarstwową. Pozostała część konstrukcji pozostała bez zmian,

II - w ścianach bocznych szkielet ograniczono do słupków i pasa dachowego, a płaską blachę poszyciową zastapiono strukturą trójwarstwową. W części środkowej dachu szkielet i blachę poszyciową zastapiono strukturą trójwarstwowa, tworzącą powłokę walcową. Pozostała część konstrukcji pozostała bez zmian, 
III - zmiany takie jak w koncepcji „II” oraz zastapienie blachy trapezowej $\mathrm{w}$ podłodze strukturą trójwarstwową.

\subsection{Modele obliczeniowe}

W celu wstępnego określenia przydatności zaproponowanych koncepcji budowy struktur nośnych rozważanych pojazdów szynowych jest niezbędna, oprócz analizy konstrukcyjnej i technologicznej, ocena porównawcza sztywności i wytrzymałości z wynikami dla szkieletowej konstrukcji klasycznej.

Niezbędne analizy sztywności i wytrzymałości wykonano metodą elementów skończonych MES korzystając z systemu ABAQUS.

Dla każdej z zaproponowanych koncepcji konstrukcji opracowano model obliczeniowy składający się z elementów powierzchniowych. Ze względu na symetrię geometrii i obciążeń modele obliczeniowe obejmują ćwiartkę konstrukcji wagonu. Na rys. 2.1 przedstawiono ogólny widok modelu obliczeniowego dla konstrukcji szkieletowej. Na rys. 2.2 pokazano fragment modelu ilustrujący wprowadzenie struktury trójwarstwowej w ścianie bocznej, a na rys. 2.3 rejon połączenia ściany bocznej i dachu wykonanego $\mathrm{w}$ znacznej części $z$ elementów trójwarstwowych, wzmocnionych jedynie pasem dachowym i słupkami ściany bocznej. Fragment modelu, w którym elementy powierzchniowe trójwarstwowe wprowadzono również w miejsce blachy podłogowej zaprezentowano na rys. 2.4.
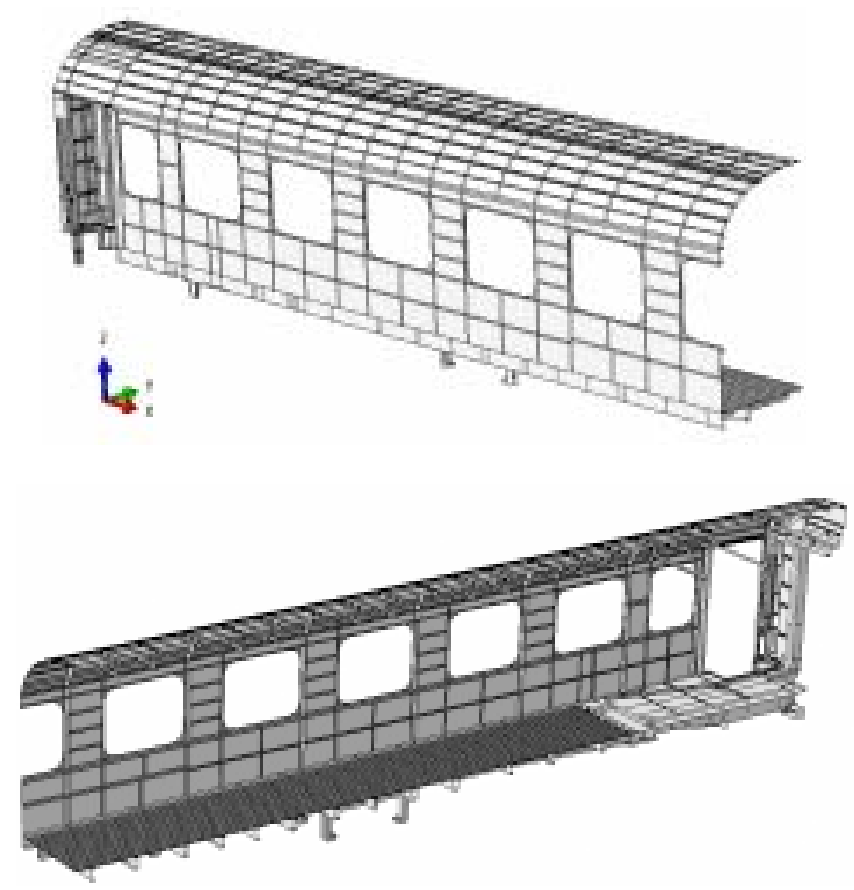

Rys. 2.1. Widok ogólny modelu obliczeniowego konstrukcji szkieletowej wagonu osobowego

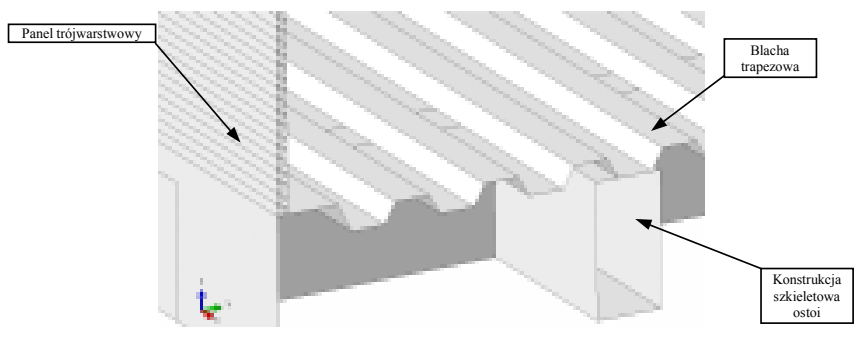

Rys. 2.2. Widok fragmentu modelu obliczeniowego połączenia trójwarstwowej ściany bocznej z ostoją (koncepcja I)

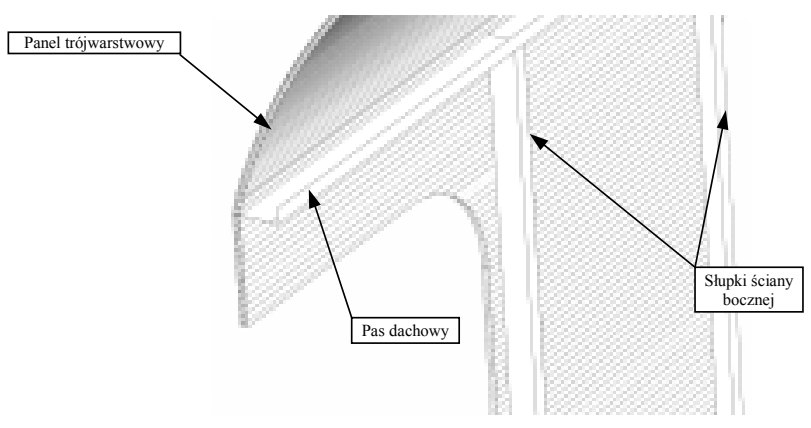

Rys. 2.3. Widok fragmentu modelu obliczeniowego połączenia trójwarstwowej ściany bocznej z dachem (koncepcja II)

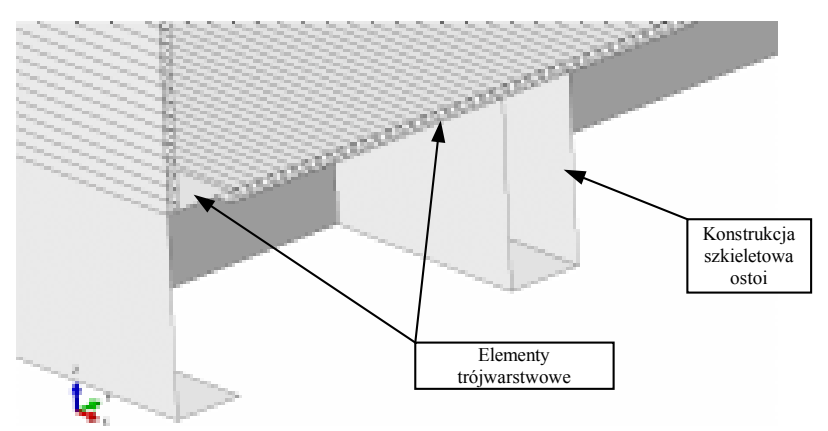

Rys. 2.4. Widok fragmentu modelu obliczeniowego z trójwarstwową ścianą boczną i panelem podłogowym (koncepcja III)

Modele obliczeniowe podzielono na elementy powłokowe typu SHELL. Połączenie blach płaskich i pofałdowanej w konstrukcji trójwarstwowej zrealizowano za pomoca połaczenia kontaktowego typu „,interaction tie”. Przykładowy podział na elementy skończone przedstawiono na rys. 2.5.

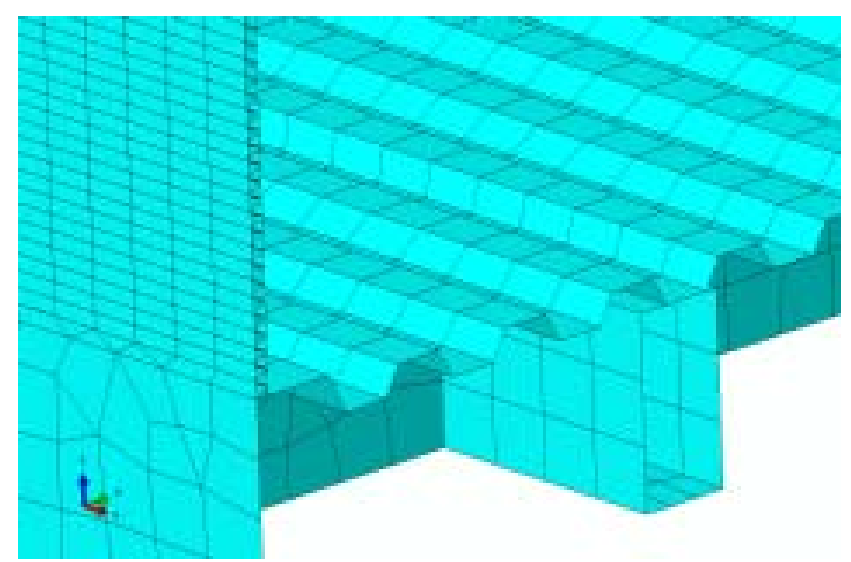

Rys. 2.5. Przykładowy podział fragmentu modelu obliczeniowego na elementy skończone 
Na podstawie wymagań normy PN-EN 12663-1 [4] określono przypadki obciążeń, dla których należałoby przeprowadzić wstępną analizę sztywności i wytrzymałości konstrukcji. Przyjęto następujące przypadki obciążenia statycznego:

a) maksymalne obciążenie pionowe wagonu ciężarem własnym i pasażerów ze współczynnikiem przeciążenia dynamicznego $\mathrm{k}=1.3$,

b) ściskanie pudła wagonu siłą $2.0 \mathrm{MN}$ w osi zderzaków,

c) ściskanie pudła wagonu siłą $2.0 \mathrm{MN}$ w osi sprzęgu,

d) rozciaganie pudła wagonu siłą $1.0 \mathrm{MN}$ w osi sprzęgu.

W obliczeniach przyjęto, że masa pudła wagonu wynosi około $35.8 \mathrm{t}$, natomiast ilość przewożonych pasażerów to 144 osoby (około $11.5 \mathrm{t}$ ).
Sposób obciążenia i podparcia dla wszystkich rozpatrywanych modeli jest jednakowy.

\subsection{Rezultaty obliczeń}

Z przeprowadzonych obliczeń wynika, że największy poziom naprężeń zredukowanych pojawia się w konstrukcji szkieletowej oraz w koncepcji „I” ze ścianami bocznymi, a także koncepcji „II” ze ścianami bocznymi i dachem o budowie trójwarstwowej, dla przypadku obciążeń wzdłużnych. Wysoki poziom naprężeń, w trapezowej blasze podłogowej, nieprzekraczający wartości dopuszczalnych (maksymalna wartość wynosi $\sigma_{\text {red }}=352 \mathrm{MPa}$ ), ma zdecydowanie charakter lokalny związany $\mathrm{z}$ zabudową różnego rodzaju wsporników na ostoi wagonu. Przedstawiono to na rys. 2.6.
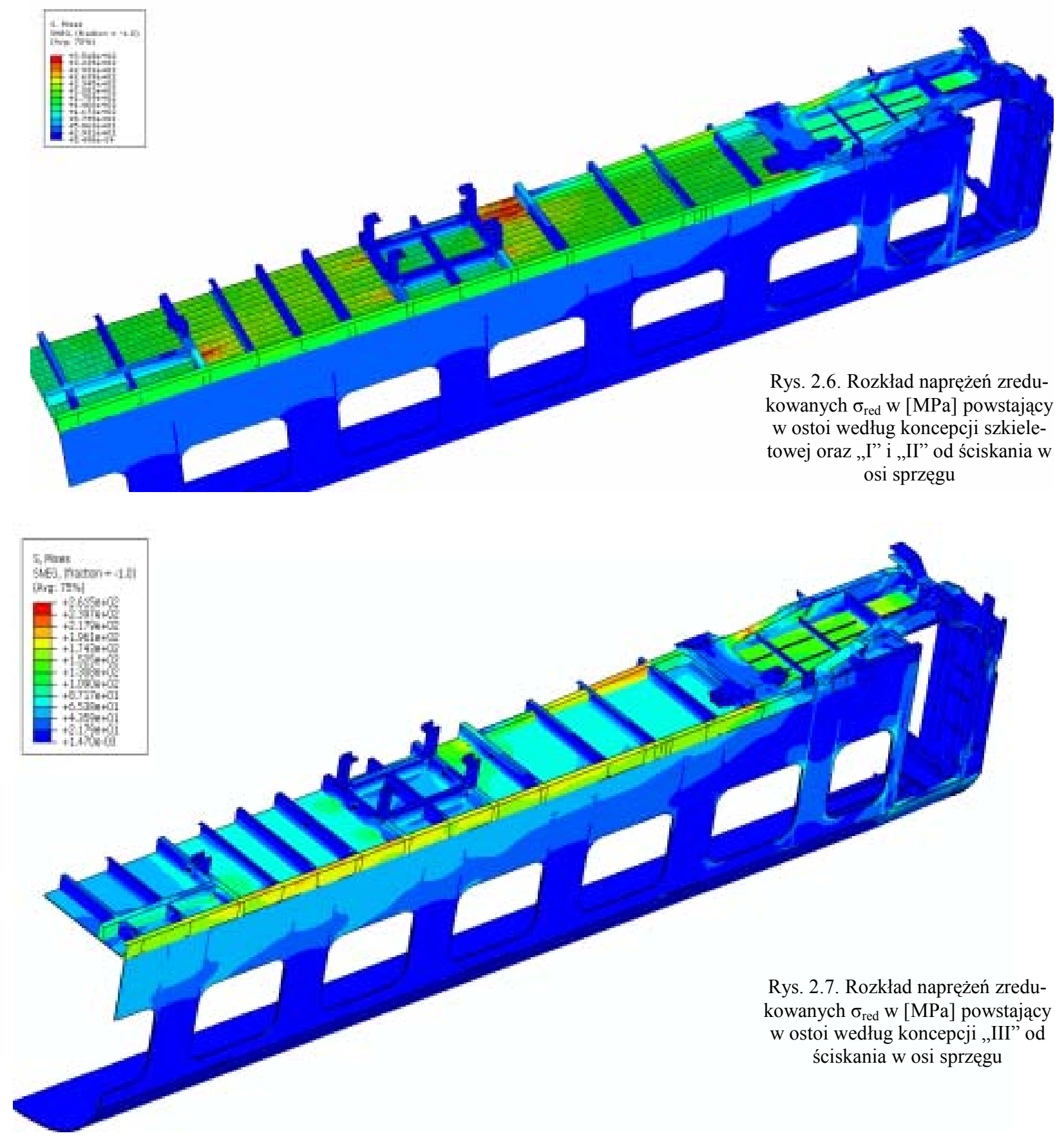
W przypadku koncepcji „III”, w której jednocześnie ściany boczne, dach i podłoga są wykonane $\mathrm{z}$ elementów powierzchniowych o budowie trójwarstwowej zmienił się rozpływ sił wewnętrznych. Spowodowane jest to głównie zastapieniem trapezowej blachy podłogowej płytą trójwarstwową. Z przeprowadzonych analiz wynika, że wówczas siły wzdłużne przenoszone są w większym stopniu przez ostojnice niż blachę podłogową, powodując spadek naprężeń w podłodze przy jednoczesnym wzroście na ostojnicach. W przypadku ściskania w osi sprzęgu wymieniony wyżej poziom naprężenia w blasze podłogowej zmniejsza się do wartości około $\sigma_{\text {red }}=200 \mathrm{MPa}$, przy wzroście $\mathrm{w}$ ostojnicy do wartości około $\sigma_{\text {red }}=240$ $\mathrm{MPa}$, co ilustruje rys. 2.7. Jednak w przypadku ściskania w osi zderzaków dla modelu z podłogą trójwarstwową, w części skrajnej ostoi, pojawiają się naprężenia o wartości większej niż dopuszczalne. Sugeruje to, że w przypadku przyjęcia takiej koncepcji rozwiązania konstrukcji należałoby wprowadzić dodatkowe zmiany konstrukcyjne w tej części ostoi.

Dla przypadku obciążenia pionowego największy poziom naprężeń, bez względu na rozważaną koncepcję konstrukcji nośnej, pojawia się w ścianie bocznej w rejonie dolnych naroży okiennych. Przykładowy rozkład przedstawiono na rys. 2.8. Wartości wahają się w przedziale od $\sigma_{\text {red }}=138 \mathrm{MPa}$ do $\sigma_{\text {red }}=161 \mathrm{MPa}$. $Z$ powyższego wynika, że zmiany konstrukcji ściany bocznej, poprzez wprowadzenie struktur trójwarstwowych, nie zmieniają znacząco poziomu naprężeń.

Zmiany proponowane w kolejnych koncepcjach rozwiązań konstrukcyjnych przyczyniają się równocześnie do obniżenia masy konstrukcji nośnej pudła wagonu osobowego. Poniżej zestawiono uzyskane wartości mas i przewidywane obniżenie procentowe (wartości wyznaczone na podstawie modelu obliczeniowego):

1) konstrukcja szkieletowa: $9990 \mathrm{~kg}$,

2) koncepcja „I” - struktura trójwarstwowa w ścianie bocznej: $\sim 9175 \mathrm{~kg}$; obniżenie masy: $\sim 8.2 \%$,

3) koncepcja „II” - struktura trójwarstwowa w ścianie bocznej i dachu: $\sim 8400 \quad \mathrm{~kg}$; obniżenie masy: $\sim 15.9 \%$,

4) koncepcja „III” - struktura trójwarstwowa w ścianie bocznej, dachu i podłodze: $\sim 8318 \mathrm{~kg}$; obniżenie masy: $\sim 16.7 \%$.

Z przedstawionych rezultatów wynika, że znaczący wpływ na masę konstrukcji mają zmiany wprowadzone w ścianie bocznej i dachu (po około $8 \%$ każdy). Najmniejsza zmiana masy pojawia się po wprowadzeniu struktury trójwarstwowej zamiast blachy trapezowej w podłodze (nie przekracza $1 \%$ ).

\section{Podsumowanie}

Z przeprowadzonych wstępnych analiz porównawczych wynika, że proponowane koncepcje rozwiązań konstrukcyjnych budowy ustrojów nośnych wagonów osobowych $\mathrm{z}$ uwzględnieniem elementów powierzchniowych o strukturze trójwarstwowej $\mathrm{z}$ rdzeniem z blachy pofałdowanej, gwarantują wystarczająca sztywność i wytrzymałość na przeniesienie podstawowych obciążeń według wymagań normy [4]. Zaleta proponowanych zmian jest, przy zapewnieniu odpowiedniej wytrzymałości, obniżenie masy konstrukcji nośnej pudła wagonu (około $16 \%$ ) Gwarantuje to zmniejszenie oddziaływania na środowisko naturalne przy tych samych możliwościach przewozowych.

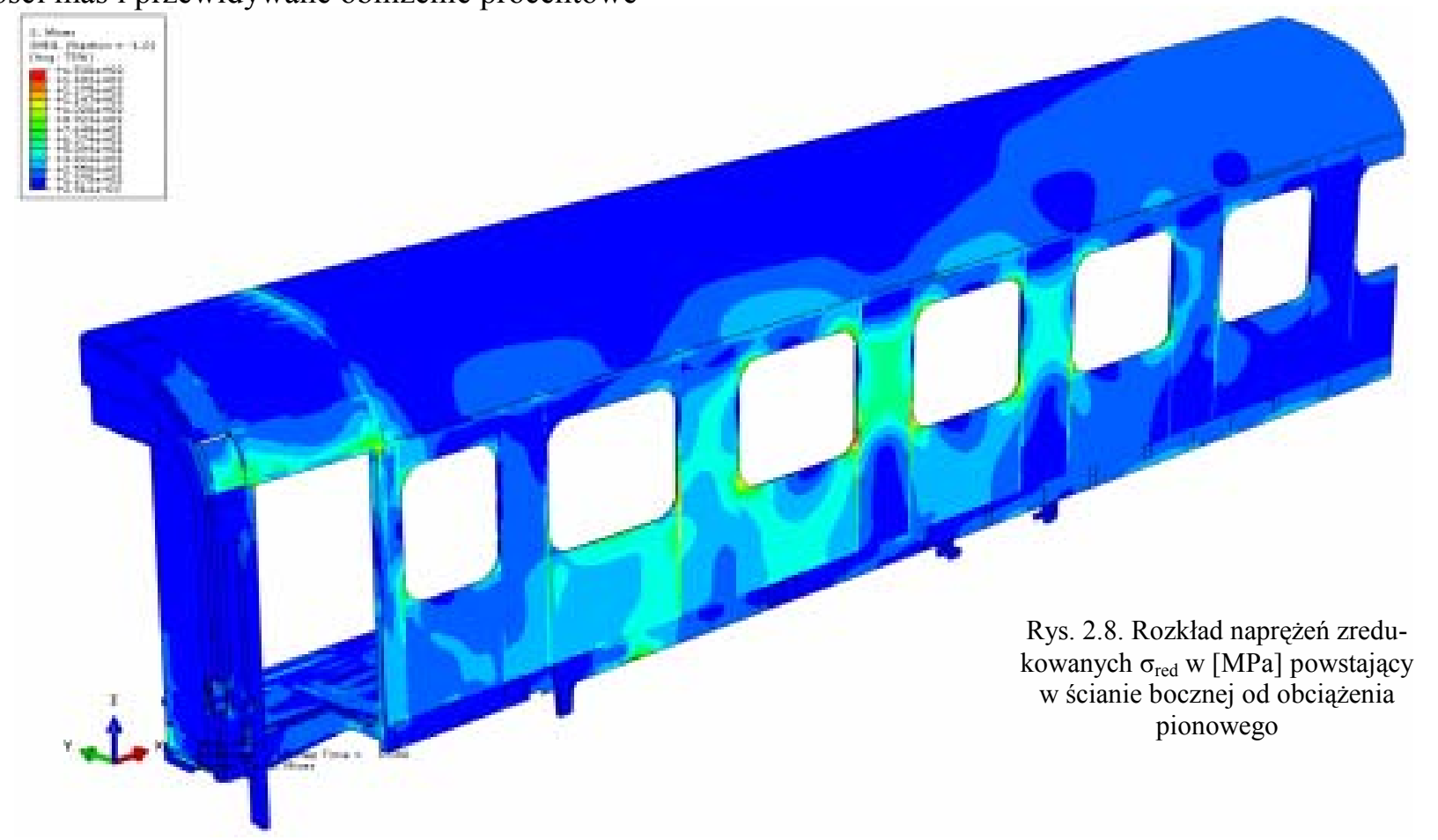




\section{Literatura}

[1] Allen H.G., Analysis and design of structural sandwich panels. Oxford, London, Edinburgh, New York, Toronto, Sydney, Paris, Braunschweig, Pergamon Press 1969.

aluminium $i$ wysokowytrzymalych tworzyw sztucznych dla budowy nadwozi i ram wózków pojazdów szynowych, Instytut Pojazdów Szynowych „TABOR”Poznań, Poznań, 2010, OR-9913 (niepublikowane).

[2] Plantema F.J., Sandwich construction. New York44] PN-EN 12663-1:2010 Kolejnictwo - Wymagania konLondon, Sydney, John Wiley\&Sons 1966.

strukcyjno-wytrzymatościowe dotyczace pudet kolejo-

[3] Modelowanie wtasności mechanicznych wybranych ultralekkich struktur wielowarstwowych wykonanych $z$ wych pojazdów szynowych - Część 1: Lokomotywy i tabor pasażerski (i metoda alternatywna dla wagonów towarowych). 